\title{
RESEARCH
}

\section{The Human CAS (Cellular Apoptosis Susceptibility) Gene Mapping on Chromosome 20q13 Is Amplified in BT474 Breast Cancer Cells and Part of Aberrant Chromosomes in Breast and Colon Cancer Cell Lines}

\author{
Ulrich Brinkmann, ${ }^{1,3}$ Maria Gallo, ${ }^{1}$ Mihael H. Polymeropoulos, ${ }^{2}$ and \\ Ira Pastan ${ }^{1}$
}

\author{
${ }^{1}$ Laboratory of Molecular Biology, Division of Basic Sciences, National Cancer Institute, National \\ Institutes of Health, Bethesda, Maryland 20892-4255; ${ }^{2}$ National Institutes of Health, National Center for \\ Human Genome Research, Bethesda, Maryland 20892 USA
}

\begin{abstract}
The CAS (cellular apoptosis susceptibility) gene is the human homolog of the yeast chromosome segregation gene CSEl. CAS may have a dual function in mammalian cells, one in apoptosis and another in cell proliferation. We have now mapped the CAS gene to chromosome 20q13. This region is known to harbor amplifications that correlate with aggressive breast cancer. Southern hybridizations with a CAS cDNA fragment and fluorescent in situ hybridization (FISH) with a PI clone containing the CAS gene show elevated copy numbers in one leukemia, three of four colon, and in three of seven breast cancer cell lines. Elevated CAS copy number in CEM leukemia and COLO201 colon cancer cells was attributable to additional copies of chromosome 20. In SW480 and COLO205 colon cancer cells CAS is part of aberrant chromosomes containing large parts of $20 \mathrm{q}$. In breast cancer cells CAS is also part of aberrant $20 \mathrm{q}$ chromosomes (MDA-MB-157 and UACC-812) or of additional 20q isochromosome in MDA-MB-134. In MDA-MB361 and BT-474 breast cancer cells CAS is separated from other markers centromeric and telomeric of CAS on 20q. MDA-MB 361 contains one additional copy of CAS, separated from the centromeric 20q control probe. BT-474 cells have up to 12 additional CAS copies that we separated from nearby telomeric and centromeric probes on $20 \mathrm{q}$ and that are translocated to abnormal chromosomes.
\end{abstract}

The CAS (cellular apoptosis susceptibility) gene is the human homolog of the essential yeast chromosome segregation gene CSE1 (Xiao et al. 1993; Brinkmann et al. 1995b). In animal cells it appears to have more than one function: one in apoptosis and another in cell proliferation. We originally isolated $C A S$ in a genetic screen for cDNAs that would render cancer cells resistant to bacterial toxins and immunotoxins (Brinkmann et al. 1995a). We found that a plasmid expressing $C A S$ antisense cDNA rendered cells resistant against apoptosis induced by ADP-ribosylating toxins (Pseudomonas and diphtheria toxin) as well as by tumor necrosis factor (TNF). This suggests that $C A S$ plays a role in apoptosis (Brink-

${ }^{3}$ Corresponding author.

E-MAlL uli@helix.nih.gov; fAX (301) 402-1344. mann et al. 1995b). CAS also appears to have a function in cell proliferation. In yeast, the homologous gene CSE 1 is involved in chromosome segregation (Xiao et al. 1993) and is also necessary for B-type cyclin degradation in mitosis (Irninger et al. 1995). Direct experimental evidence for a role of $C A S$ in the proliferation of human cells was a correlation of CAS expression with cell proliferation. CAS is preferentially expressed in tissues containing proliferating cells (testis or fetal liver), in rapidly growing tumor cell lines, and in fibroblasts that are stimulated to grow by serum addition (Brinkmann et al. 1995b).

The association of $C A S$ with cell proliferation as well as apoptosis raises the possibility that $C A S$ might be a cancer-related gene. Several genes that control cell growth and apoptosis, like p53, bcl-2, 
BRINKMAN ET AL.

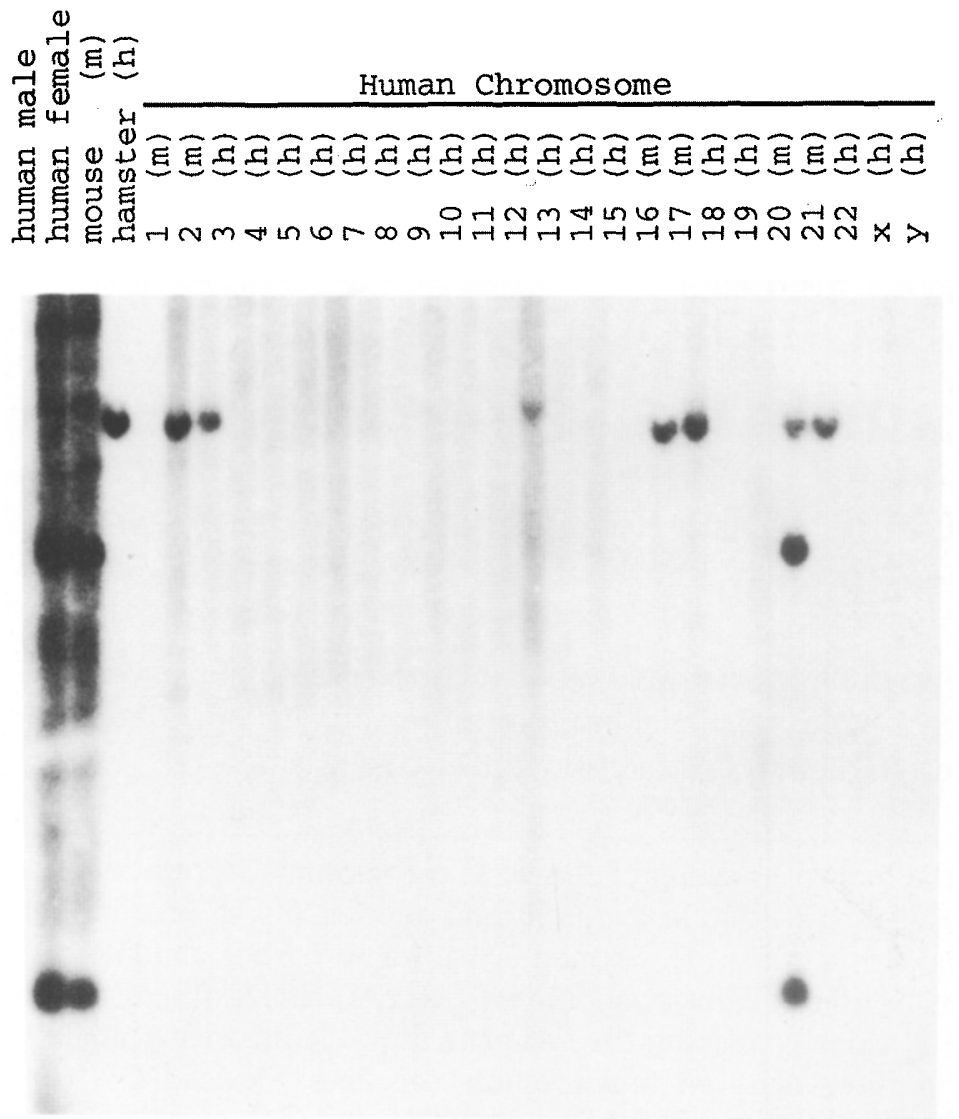

Figure 1 CAS MAPS on chromosome 20. Southern blots of Pstldigested human genomic male and female, mouse, and hamster DNA and genomic DNA from somatic cell hybrids containing single human chromosomes were hybridized with a CAS CDNA probe. The mouse $(m)$ or hamster $(h)$ background of each line is indicated next to the number of the human chromosome. The CAS CDNA probe hybridizes under stringent conditions to mouse but not to hamster DNA, to human female and male DNA, and to human chromosome 20 . The weak signal in the band of chromosome 12 is from a previous (unrelated) hybridization that was not completely stripped of the filter. There is no indication of a gene with homology to CAS on chromosome 12.

cyclin $D$, and myc (Tsujimoto et al. 1985; Lowe et al. 1993; Hartwell and Kastan 1994; Hermeking and Eick 1994), play a role in cancer if they are mutated or if their expression is altered by genomic rearrangements. Another hint for a possible involvement of CAS in cancer is the function of the yeast homolog gene CSE1. Defects in CSE1 lead to abnormal chromosome segregation in yeast. If the human homolog CAS gene were to have a similar function, alteration of CAS expression might cause abnormal chromosome segregation. Chromosome aneuploidies or aberrant chromosomes are observed frequently in cancer cells. Here we show that the $C A S$ gene maps on chromosome $20 \mathrm{q} 13$ close to a region that often contains amplifications associated with aggressive breast cancer. We also show that CAS is located on aberrant chromosomes in colon and breast cancer cell lines and that $C A S$ is specifically amplified in BT-474 breast cancer cells.

\section{RESULTS \\ CAS Maps on 20q13}

The CAS gene was mapped to chromosome 20 by hybridization of genomic DNA from mouse or hamster somatic cell hybrids containing different human chromosomes with a CAS cDNA fragment (cDNA position 2100-2536, 1). Figure 1 shows that two PstI fragments of human male and female genomic DNA hybridize with this probe. At least two hybridizing fragments were expected because the CAS probe contained an internal PstI site. Both CAS fragments were detected in DNA of the mouse line that contains human chromosome 20.

For finer mapping, the human Centre d'Etude du Polymorphisme Humaine (CEPH) YAC Megabase library (Cohen et al. 1993) was screened by PCR with primers that amplify a 90-bp CAS-specific fragment from CAS cDNA and from human genomic DNA (see Methods). One yeast artificial chromosome (YAC) clone, 953$\mathrm{B}-4$, was positive with these primers. Microsatellite markers on and near YAC 953-b4 were identified and used to map the YAC relative to typed microsatellites (Polymerpoulos et al. 1993; Gyapay et al. 1994). YAC 953-B-4 overlaps with YACs containing the marker D20S176 on the long arm of human chromosome 20 indicating that the CAS gene lies within $2-3 \mathrm{Mb}$ of that marker. This gene location, which was confirmed by fluorescent in situ hybridization (FISH; see below; Fig. 2), is close to the 20q13 region that is often amplified in breast, colon, and bladder cancer (Reznikoff et al. 1994; Tanner et al. 1994).

\section{Southern Analyses of CAS Copy Number}

The initial gene-mapping experiments established that $C A S$ is linked to the amplification region in 20q13. However, CAS might be close to that region but not actually in it. Also, the 20q13 

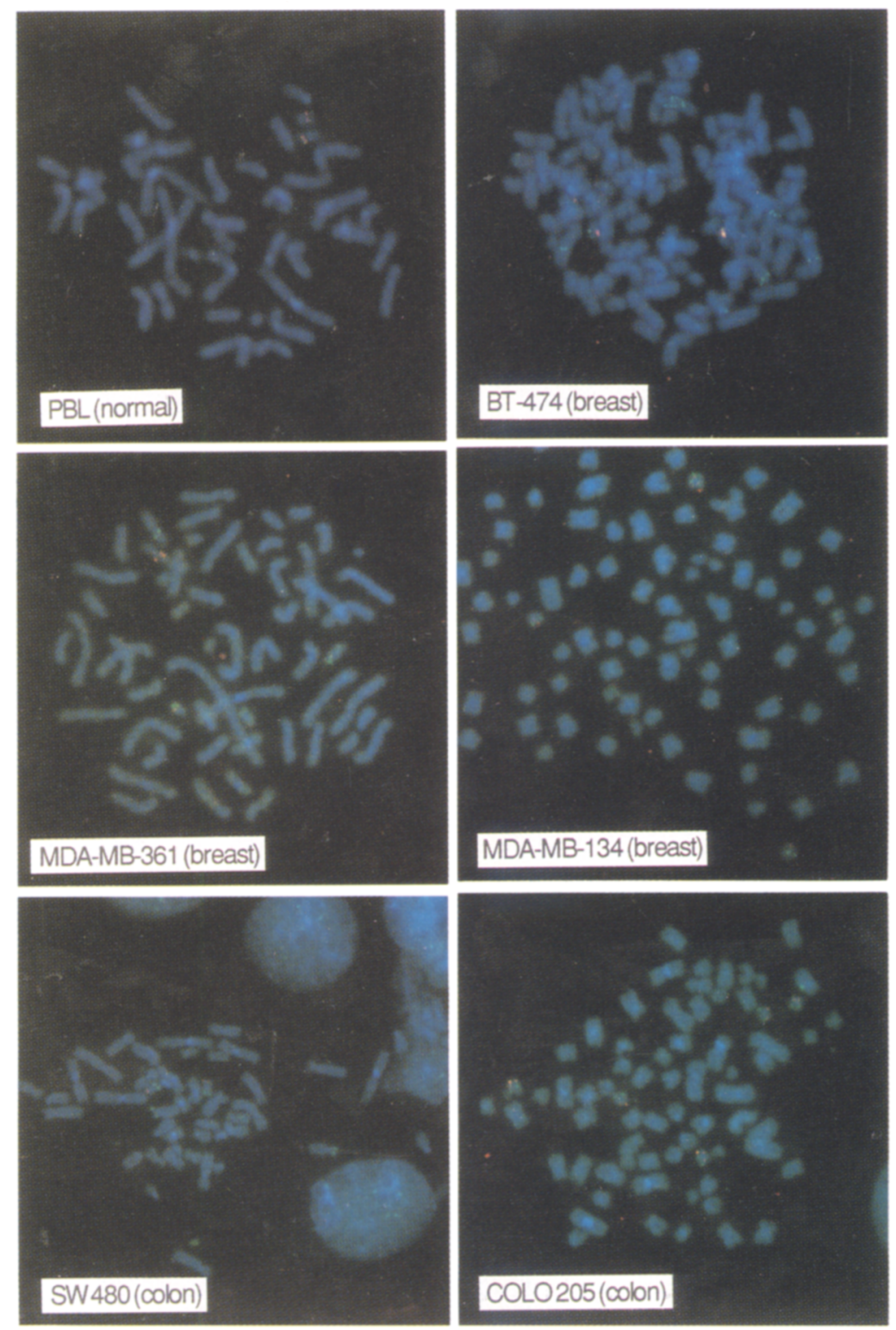

Figure 2 Fluorescent in situ hybridization. Metaphase chromosomes of PBLs, breast cancer cells BT-474, MDA-MB-134, MDA-MB-361, and SW480 and COLO205 colon cancer cells were hybridized with digoxigenin-labeled P1/CAS and biotin-labeled control probes P1/2672 and P1/2567 (close to CAS on 20q) or P1/5461 (20p). (A) PBLs; (B) BT-474; (C)MDA-MB-134; (D) MDA-MB-361 with P1/CAS and P1/2672; (E) SW480; $(F)$ COLO205 cells with P1/CAS and P1/5461 (20p). P1/CAS is visualized by fluorescein-anti-digoxigenin antibody (green) and controls with Texas Red-avidin (red). COLO201 colon, UACC812, and MDA-MB-157 breast cancer and CEM leukemia cells were also analyzed by $\mathrm{FISH}$ and had extra $20 \mathrm{q}$ marker chromosomes or additional copies of whole chromosome 20 (not shown; see Table 1).

region is, at least in breast cancer, not a homogeneous amplicon but consists of different regions that lie close together and contain various degrees of possibly independent amplifications (Tanner et al. 1994). To test whether the CAS gene itself is amplified, we screened genomic DNA of cell lines from a variety of cancers (breast, colon, bladder, gastric, ovary, prostate, melanoma, leukemia, and lymphoma, and others; Table 1) by Southern hybridization. We compared the strength of the $C A S$ signal to that produced by two control probes: $\beta$-actin and proliferating cell nuclear antigen (PCNA). Then, the ratio of CAS-specific signals to control signals was compared to the signal ratios of the tumor cell lines. Table 1 lists the PhosphorImager quantitation of Southern hybridizations with CAS and control probes using DNA from various cancer cell lines. Most cell lines did not show increased hybridization signals with the CAS-specific probe. However, CAS signals were elevated in BT474 breast cancer cells and in the colon cancer cell lines SW480, COLO201, and COLO205. This observation is in agreement with previous observations of amplifications in the long arm of chromosome 20 in breast and colon cancers (Reznikoff et al. 1994; Tanner et al. 1994). In addition, we found elevated CAS signals in CEM leukemia cells (Table 1).

\section{FISH with P1/CAS}

More detailed information about CAS amplification in cancer cells was obtained by FISH (Thompson and Gray 1993). To do this, a P1 phage containing the CAS gene (P1/CAS) was obtained from a human P1 genomic library. P1/CAS contains most (and probably all) of the CAS gene because (1) PCR primers for the 5' portion and $3^{\prime}$ portion of the cDNA amplify $5^{\prime}$ and $3^{\prime}$ CAS gene fragments when using P1/CAS as template, (2) $5^{\prime}$ - and 3 '-end cDNA probes hybridize to P1/CAS, and (3) DNA sequencing reveals the presence of the CAS coding region in that phage (not shown). P1/CAS was labeled with digoxigenin and hybridized to inter- 
BRINKMAN ET AL.

Table 1. CAS Amplification in Cancer Cell Lines

\begin{tabular}{|c|c|c|c|c|c|c|}
\hline \multicolumn{2}{|l|}{ Cell line } & \multirow{2}{*}{$\begin{array}{l}\begin{array}{l}\text { Southern } \\
\text { signal } \\
\text { elevation }\end{array} \\
\text { N.D. }\end{array}$} & \multirow{2}{*}{$\begin{array}{l}\text { FISH } \\
\text { CAS } \\
\text { copies } \\
2\end{array}$} & \multirow{2}{*}{$\begin{array}{l}\text { Chromosomes/ } \\
\text { cell }\end{array}$} & \multicolumn{2}{|c|}{ Amplification } \\
\hline PBLs & $\begin{array}{l}\text { normal } \\
\text { blood }\end{array}$ & & & & - & control \\
\hline SK-BR3 & $\begin{array}{l}\text { breast } \\
\text { cancer }\end{array}$ & - & & & & \\
\hline MCF-7 & $\begin{array}{l}\text { breast } \\
\text { cancer }\end{array}$ & - & & & & \\
\hline MDA-MB-134 & $\begin{array}{l}\text { breast } \\
\text { cancer }\end{array}$ & N.D. & 4 & 86 & $<2$-fold & $\begin{array}{c}\text { normal chromosome; } 20+ \\
20 \mathrm{q} \text { isochromosome }\end{array}$ \\
\hline MDA-MB-157 & $\begin{array}{l}\text { breast } \\
\text { cancer }\end{array}$ & N.D. & $2-6$ & 54 & $<3$-fold & $\begin{array}{l}\text { large } 20 q \text { marker } \\
\text { chromosomes }\end{array}$ \\
\hline UACC-812 & $\begin{array}{l}\text { breast } \\
\text { cancer }\end{array}$ & N.D. & 3 & 60 & $<2$-fold & $\begin{array}{l}\text { no normal } 20,20 q \text { marker } \\
\text { chromosomes }\end{array}$ \\
\hline MDA-MB-361 & $\begin{array}{l}\text { breast } \\
\text { cancer }\end{array}$ & N.D. & 3 & 56 & $<2$-fold & $\begin{array}{l}\text { aberrant chromosomes, } \\
\text { CAS separated from } \\
\text { control }\end{array}$ \\
\hline BT-474 & $\begin{array}{l}\text { breast } \\
\text { cancer }\end{array}$ & + & $8-16$ & $95-100$ & 3-to 8-fold & $\begin{array}{l}\text { no normal chromosome } 20, \\
\text { CAS-specific amplification } \\
\text { and translocations }\end{array}$ \\
\hline COLO201 & $\begin{array}{l}\text { colon } \\
\text { cancer }\end{array}$ & + & 5 & $57-60$ & $\sim 2$-fold & extra chromosome 20 \\
\hline COLO205 & $\begin{array}{l}\text { colon } \\
\text { cancer }\end{array}$ & + & 5 & $65-69$ & $\sim 2$-fold & $\begin{array}{l}\text { extra chromosome } 20+ \\
\text { large } 20 q \text { containing } \\
\text { marker chromosomes }\end{array}$ \\
\hline LS174T & $\begin{array}{l}\text { colon } \\
\text { cancer }\end{array}$ & - & & & & \\
\hline SW480 & $\begin{array}{l}\text { colon } \\
\text { cancer }\end{array}$ & + & $4-6$ & $48-55$ & $\sim 2$-fold & $\begin{array}{l}\text { aberrant chromosomes with } \\
\text { large } 20 q \text { amplification } \\
\text { (20q marker } \\
\text { chromosomes) }\end{array}$ \\
\hline K562 & leukemia & - & & & & \\
\hline HL60 & leukemia & - & & & & \\
\hline KG1 & leukemia & - & & & & \\
\hline CEM & leukemia & + & $6-8$ & $83-86$ & -2-fold & extra chromosome 20 \\
\hline $\begin{array}{l}\text { Southern blots wi } \\
\text { as described in } \mathrm{N} \\
\text { numbers of CAS } \mathrm{p} \\
\text { ploidy. Chromoso } \\
\text { CEM, which shou } \\
\text { somes; thus, the r } \\
\text { Raji, Daudi), mel } \\
\text { (CRL1739, N87, } \\
\text { HeLa, epidermoid } \\
\text { indication of CAS }\end{array}$ & $\begin{array}{l}\text { lethods. The } \\
\text { er cell, and th } \\
\text { me number/c } \\
\text { ld contain } 45 \\
\text { lumber of chr } \\
\text { nomas (C36 } \\
\text { ITG1, HTB-10 } \\
\text {; Huh7, Hep3 } \\
\text { amplification }\end{array}$ & $\begin{array}{l}\text { enomic DNA } \\
\text { number of CA } \\
\text { e number of cc } \\
\text { ell is chromosc } \\
-47 \text { chromosor } \\
\text { omosomes do } \\
\text { 1, HTB63, Fen } \\
\text { 3), prostate ca } \\
\text { B, liver; HTB7s } \\
\text { in these cells. }\end{array}$ & $\begin{array}{l}\text { ontrol sign } \\
\text { omes obse } \\
\text { mes but w } \\
\text { not reflec } \\
\text { nX, A325, } \\
\text { incer (LNC } \\
\text { 9, HTB80, }\end{array}$ & $\begin{array}{l}\text { dized with }{ }^{32} \mathrm{P} \text {-labeled } \\
\text { y FISH on inter- and } \\
\text { ls with centromeric ce } \\
\text { ved by FISH and agre } \\
\text { e find } 83-86 \text { chromos } \\
\text { true ploidy. In additi } \\
\text { Molt4), ovarian can } \\
\text { aP, DU145, PC3), bla } \\
\text { pancreas; U245, T98C }\end{array}$ & $\begin{array}{l}\text { CAS and actin } \\
\text { metaphase chr } \\
\text { ntrol P1/2672 } \\
\text { es with publishe } \\
\text { omes. BT-474 } \\
\text { n, we evaluate } \\
\text { er (OVCAR2, } \\
\text { dder cancer (H7 } \\
\text { glioblastoma) }\end{array}$ & $\begin{array}{l}\text { probes and the signals quantitated } \\
\text { omosomes (Fig. 2) reflect absolute } \\
\text { r the } 20 \text { p control P1/5461, the cell } \\
\text { d data (Hay et al. 1992), except for } \\
\text { ells contain many marker chromo- } \\
\text { d several lymphomas (K562, CA46, } \\
\text { OVCAR3, CRL1874), gastric cancer } \\
\text { B2, HTB3, T24), and others (A431, } \\
\text { by Southern blots without finidng }\end{array}$ \\
\hline
\end{tabular}

and metaphase chromosomes and detected with fluorescein-labeled anti-digoxigenin antibodies. As reference probes for the determination of the relative amplification status of $C A S$, we used the following biotin-labeled P1 clones: P1/2672, which hybridizes on $20 \mathrm{q}$, centromeric to the position of the CAS gene in 20q13; P1/2567, which is telomeric to CAS; and P1/5461, which maps to the $\mathrm{p}$ arm of chromosome 20 . The controls were visualized with Texas Red-avidin. 


\section{MAPPING ON 20Q13 AND AMPLIFICATION OF HUMAN CAS}

\section{Normal Cells}

Figure 2 shows FISH with P1/CAS (green) and P1/ 2672 or P1/5461 (red) on metaphase chromosomes from peripheral blood lymphocytes (PBLs). The PBLs show two copies with each probe on the long arm of chromosome 20. Metaphase chromosomes show a linear orientation. $\mathrm{P} 1 / 2672$ is centromeric and P1/2567 (not shown) is telomeric to P1/CAS. This confirms the position of P1/CAS on 20q13 as defined by YAC mapping.

\section{Breast Cancer Cells}

We then analyzed five breast cancer cell lines: BT-474, MDA-MB-157, UACC-812, MDA-MB361 , and MDA-MB-134. BT-474 was chosen because Southern analyses indicated potential $C A S$ amplification (Table 1). The others were evaluated because $20 q 13$ amplifications occur frequently in breast cancer and because such amplifications were already demonstrated by comparative genomic hybridization (CGH) and FISH with other probes in UACC-812, MDA-MB-157, and BT-474 (Tanner et al. 1994). On BT-474 cells (Fig. 2), pairwise hybridization showed 8-16 signals with P1/CAS but only two signals per cell with the centromeric control probe. The two centromeric signals are linked to P1/CAS in a chromosome that appears to be the remainder of chromosome 20 . Thus, relative to the region centromeric of $C A S$, as defined by the control phage (P1/2672), the CAS gene is amplified four- to eightfold. Pair-wise FISH on BT-474 cells with P1/ CAS and P1/2567 as a control that hybridizes telomeric of CAS showed 8-12 signals (in another experiment up to 18) with $C A S$ and 4 signals with P1/2567. Two of the four control signals were linked to CAS; the others were found on another chromosome separate from CAS. BT- 474 cells do not contain a normal chromosome 20; all three probes hybridized to morphologically abnormal chromosomes. The amplified CAS gene is translocated to different abnormal chromosomes, each containing one to five copies of CAS. No double minute chromosomes were seen in BT474 cells.

The other breast cancer cell lines that we analyzed, MDA-MB-134, -MB-157, -MB-361, and UACC-812, contained three to six copies of CAS, mainly present on abnormal marker chromosomes. MDA-MB-361 contains two normal copies of chromosome 20 (with $C A S$ ) and one addi- tional copy of CAS separated from the telomeric $20 \mathrm{q}$ control on an aberrant chromosome. These cells also harbor a third copy of the control gene separated from CAS on another abnormal chromosome. MDA-MB-134 cells contain four to five copies of CAS, two to three normal copies of chromosome 20 , and two CAS genes on a $20 \mathrm{q}$ isochromosome. UACC-812 and MDA-MB-157 contain three to six copies of CAS as well as of the centromeric control. Both signals remain linked and are found on abnormal chromosomes. UACC-812 cells do not contain a normal chromosome 20. In addition, we observed that the centromeric control probe is amplified to a higher degree than CAS (to five to eight copies). This is consistent with the observation of a second amplification "peak" centromeric from CAS in this cell line (Tanner et al. 1994).

\section{Colon Cancer and Leukemia Cells}

Three colon cancer cell lines (SW480, COLO201, COLO205) were identified as amplification candidates by Southern analyses (Table 1) and therefore analyzed by FISH with P1/CAS, the control probes described previously, and an additional $20 \mathrm{p}$ probe (P1/5461). We found that similar to MDA-MB-157 and UACC-812 cells and in contrast to BT-474 cells, CAS is located on aberrant chromosomes containing parts of $20 \mathrm{q}$ in SW480 and COLO205. Extra CAS copies are linked to $20 \mathrm{q}$ controls but separated from 20p (Fig. 2). The elevated copy number that is apparent in Southern blots of COLO201 (colon) and CEM (leukemia) cells (Table 1) is attributable to extras copies of chromosome 20 . We found five copies of chromosome 20 per cell in COLO201 cells and six to eight copies per cell in CEM.

\section{DISCUSSION}

We have mapped the human CAS gene, which is associated with cell proliferation and apoptosis (Brinkmann et al. 1995b), on the long arm of chromosome 20 (q13). Southern hybridizations and FISH analyses show that CAS is specifically amplified four- to eightfold in BT-474 breast cancer cells. In addition, the CAS gene has spread in these cells to several abnormal chromosomes, each containing one to five copies of CAS. The copy number of $C A S$ is also elevated in MDA-MB361 and MDA-MB-157 breast cancer cell lines, SW480, COLO201 and COLO205 colon cancer 
BRINKMAN ET AL.

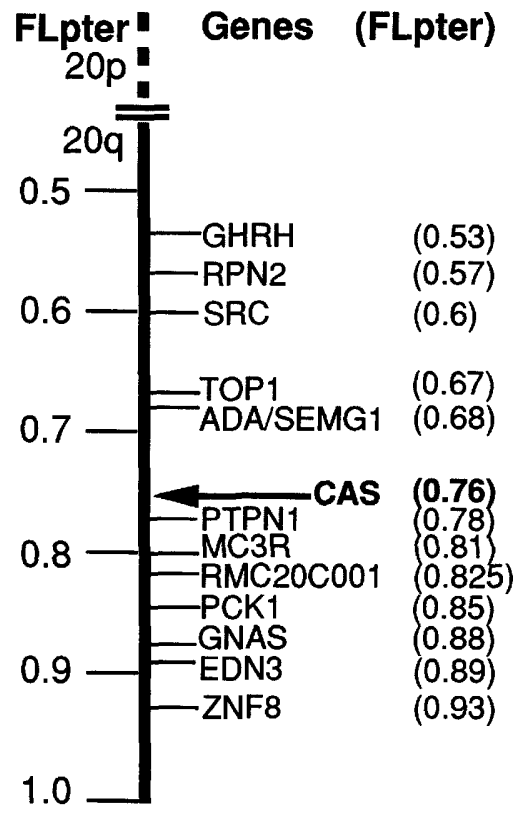

Figure 3 Localization of CAS on $20 q 13$. The localization of CAS relative to other markers and amplification regions on $20 q 13$ is shown on an ideogram that was adapted from Tanner et al. (1994) with permission of $\mathrm{O}$. Kallioniemi. (GHRH) growth hormone-releasing factor; (RPN2) riboporin 2; (SRC) src oncogene; (TOP1) topoisomerase $1 ;$ (ADA) adenosine deaminase; (SEMG1) seminogelin 1; (PTPN1) protein tyrosine phosphatase; (MC3R) melanocortin-3 receptor; (RMC20C001) amplification probe defined by Tanner et al. (1994); (PCK1) PEP carboxykinase; (GNAS) guanosine NT-binding protein; (CHRNA4) cholergic receptor $\alpha-4$; (EDN3) endothelin 3; (ZNF8) zinc finger protein 8.

cells lines, and CEM leukemia cells. But in these cells (except for MDA-MB-361), they are part of large $20 \mathrm{q}$ aberrations (marker chromosomes) or extra copies of chromosome 20.

Amplification of the $20 \mathrm{q} 13$ region in which the human CAS gene is located correlates with aggressive breast cancer (Kallioniemi et al. 1994; Tanner et al. 1994). Amplifications in 20q are also associated with immortalization and genomic instability of uroepithelial cells transformed with the human papilloma virus $16 \mathrm{E} 6$ gene, and 20q amplifications have been reported to be present also in colon and bladder cancer (Reznikoff et al. 1994). Inspection of the karyotypes of cancer cell lines indicates that part or all of chromosome 20 is overrepresented relative to other chromosomes in many cancer cell lines. These are not only of breast, colon, and bladder origin but also in lung cancer, gliomas, and mela- nomas (Hay et al. 1992). The correlation of $20 \mathrm{q}$ (particularly q13) amplification with an agressive type of breast cancer had led to the hypothesis that this region probably contains one or more novel oncogenes whose amplification may cause an aggressive cancer phenotype (Tanner et al. 1994).

CAS maps on $20 \mathrm{q} 13$ indicating that it is located close to the same amplification region that is described for cell lines and primary tumors (Tanner et al. 1994). The CAS gene is amplified in BT-474 breast cancer cells (which carry 20q13 amplifications) to a lesser degree than the maximally amplified 20q13 (Flpter 0.825) region in these cells. CAS, on Flpter 0.76 (A. Kallioniemi, and O. Kallioniemi, pers. comm.; see Fig. 3) is amplified four- to eightfold without being linked to markers $\sim 2 \mathrm{Mb}$ centromeric and telomeric from CAS. CAS is amplified to a higher degree than those markers. Flpter 0.825 is telomeric of $C A S$ and of the control and is again amplified $>10$-fold (Tanner et al. 1994; RMC20C001 in Fig. $3)$. This shows that the $20 \mathrm{q} 13$ amplification in BT-474 cells consists not of a homogenous amplicon, but of different regions that lie close together, with various independent amplifications. The observation of the separation of the site of hybridization of P1/CAS and P1/2726 in BT-474 cells as well as in the MDA-MB-361 breast cancer cell line suggests that the $\mathrm{q} 13$ region of chromosome 20 may often be unstable in breast cancer cells. In BT-474 cells the amplified CAS gene is present on various abnormal chromosomes in different (one to five) copy numbers. It appears as if $C A S$ has spread to other chromosomes by independent translocations or possibly transposonlike duplications of the CAS-containing $20 \mathrm{q}$ region. The latter possibility might explain how the CAS gene integrates into other chromosomes, whereas nearby DNA regions on either side of $C A S$ do not follow the distribution of CAS. Alternatively, the $C A S$ gene could have been present on double minutes and then integrated into another chromosome, but no double minutes were detected in BT- 474 cells.

So far, known candidate genes mapping on 20q (among them, e.g., protein tyrosine phosphatase, zinc finger protein 8 , or the Src oncogene) were excluded as being the amplified genes correlating with aggressive cancer phenotype (Tanner et al. 1994). This indicates that one or more new oncogenes lie in this region. The reasons to believe that CAS may be one of the genes in this region that are associated with cancer are 


\section{MAPPING ON 20Q13 AND AMPLIFICATION OF HUMAN CAS}

(1) CAS is associated with cell proliferation and apoptosis, a phenotype that resembles that of genes like myc (although CAS is not homologous to $m y c$ ), and (2) $C A S$ may, like the yeast homolog CSE1 gene, be involved in segregation of chromosomes in mitosis. Further analyses are required to evaluate the possibility that the $C A S$ gene participates in the development or progression of some human cancers.

\section{METHODS}

\section{Southern Analyses}

Genomic DNAs from cancer cell lines and Southern blots were prepared by standard techniques (Sambrook et al. 1989). The CAS probe, a 436-bp Asp700-XbaI cDNA insert fragment from pCDM/HE17 (Brinkmann et al. 1995a,b) random prime-labeled with ${ }^{32} \mathrm{P}$ to $-10^{9} \mathrm{cpm} / \mu \mathrm{g}$ was hybridized for $15 \mathrm{hr}$ at $50^{\circ} \mathrm{C}$ in $50 \%$ formamide to a somatic cell hybrid blot (ONCOR) or to Southern blots containing EcoRI-cut genomic DNA from cancer cell lines. The signals from cell line blots hybridized with $C A S$ and control probes were quantitated on a Molecular Dynamics PhosphorImager. Variability in the amount of blotted DNA was compensated by determining the ratio between $C A S$ and control signals that was set to $\mathbf{1}$ for human placenta DNA. Other samples were calculated relative to that. We used actin (on chromosome 7) as control probe. Chromosome 7 is overrepresented in some cancer cells. Therefore, the use of actin as control for comparisons to signals from genes on other chromosomes will result in conservative copy number estimation, and increases relative to actin correspond likely to gene copy number increase. We used a PCNA probe as additional 20p control.

\section{Isolation of CAS Gene Containing YAC and PI Clones}

A6 YAC containing the CAS gene was identified by PCR screening (Polymeropoulos et al. 1993) with CAS-specific primers 5'-GACATCCCGTCTTCCTATATG-3' (forward) and 5'-AAGAAGCCTCACTAGAGCAGGA-3' (reverse). The program "yacsr" (M.H. Polymeropoulos, unpubl.) was used to locate microsatellite markers on or near the obtained YAC address and position it relative to known markers. A P1 phage containing the CAS gene (P1/CAS) was obtained from a human P1 genomic library by PCR screening (Genome Systems, St. Louis, MO) with the same primers that we used for the YAC screen.

\section{FISH}

Interphase and metaphase chromosomes were hybridized with digoxigenin-dUTP-labeled P1/CAS and biotin-dUTPlabeled control probes $\mathrm{P} 1 / 2672$ and P1/2567 (close to CAS on 20q) or P1/5461 (20p). P1/CAS was visualized by fluorescein-anti-digoxigenin antibody (green) and the controls with Texas Red-avidin (red), using a triple band pass filter set and DAPI counterstain. FISH analyses were performed by M. Valentine at Genome Systems. The control clones P1/2672 and P1/2567 are from Genome Systems and were mapped previously (M. Valentine, pers. comm.) $\sim 2 \mathrm{Mb}$ centromeric (2672) and telomeric (2567) from CAS on chromosome 20 or on 20p (P1/5461).

\section{ACKNOWLEDGMENTS}

We thank E. Lovelace and I. Margulies for cell culture, E. Brinkmann for probe preparations and hybridizations, O.P. Kallioniemi for providing the Flpter location of CAS and for permission to use data for generation of the ideogram of the CAS location, and J. Trent for suggestions. For M.G. this project is part of her Ph.D. thesis. The GenBank accession number of CAS is U33286.

The publication costs of this article were defrayed in part by payment of page charges. This article must therefore be hereby marked "advertisement" in accordance with 18 USC section 1734 solely to indicate this fact.

\section{REFERENCES}

Brinkmann, U., E. Brinkmann, and I. Pastan. 1995a. Expression cloning of cDNAs that render cancer cells resistant to Pseudomonas and diphtheria toxin and immunotoxins. Mol. Med. 1: 206-216.

Brinkmann, U., E. Brinkmann, M. Gallo, I. Pastan. 1995b. Cloning and characterization of a cellular apoptosis susceptibility gene, the human homologue to the yeast chromosome segregation gene CSE1. Proc. Natl. Acad. Sci. 92: 10427-10431.

Cohen, D., I. Chumakov, and J. Weissenbach. 1993. A first-generation physical map of the human genome. Nature 366: 698-701.

Gyapay, G., J. Morrissette, A. Vignal, C. Dib, C. Fizames, P. Millasseau, S. Marc, G. Bernardi, M. Lathrop, and I. Weissenbach. 1994. The 1993-94 genethon human genetic linkage map. Nature Genet. 7: 246-339.

Hartwell, L.H. and M.B. Kastan. 1994. Cell cycle control and cancer. Science 266: 1821-1828.

Hay, R., J. Caputo, T.R. Chen, M. Macy, P. McClintock, and Y. Reid. 1992. Cell lines and hybridomas, 7th ed. American Type Culture Collection, Rockville, MD.

Hermeking, H. and D. Eick. 1994. Mediation of c-Myc-induced apoptosis by p53. Science 265: 2091-2093.

Irninger S., S. Platti, C. Michaelis, and K. Nasmyth. 1995. Genes involved in sister chromatid separation are needed for B-type cyclin proteolysis in budding yeast. Cell 81: 269-278.

Kallioniemi, A., O.P. Kallioniemi, J. Piper, M. Tanner, T. Stokke, L. Chen, H.S. Smith, D. Pinkel, J.W. Gray, and F.M. Waldman. 1994. Detection and mapping of amplified DNA sequences in breast cancer by 


\section{BRINKMAN ET AL.}

comparative genomic hybridization. Proc. Natl. Acad. Sci. 91: $2156-2160$.

Lowe, S.W., E.M. Schmitt, S.W. Smith, B.A. Osborne, and T. Jacks. 1993. p53 is required for radiation-induced apoptosis in mouse thymocytes. Nature 362: 847-849.

Polymeropoulos, M.H., H. Xiao, J.M. Sikela, M. Adams, J.C. Venter, and C.R. Merrill. 1993. Chromosomal distribution of 320 genes from a brain cDNA library. Nature Genet. 4: 381-386.

Reznikoff, C.A., C. Belair, E. Savelieva, Y. Zhai, K. Pfeifer, T. Yeager, K.J. Thompson, S. DeVries, C. Bindley, and M.A. Newton. 1994. Long-term genome stability and minimal genotypic and phenotypic alteration in HPV16 E7-, but not E6-, immortalized human uroepithelial cells. Genes \& Dev. 8: 227-2240.

Sambrook, J., E.F. Fritsch, and T. Maniatis. 1989. Molecular cloning: A laboratory manual, 2nd ed. Cold Spring Harbor Laboratory Press, Cold Spring Harbor, NY.

Tanner, M.M., M. Tirkkonen, A. Kallioniemi, C. Collins, T. Stokke, R. Karhu, D. Kowbel, K. Shadravan, M. Hintz, W.L. Kuo, F.M. Waldman, J.J. Isola, J.W. Gray, and O.P. Kallioniemi. 1994. Increased copy number at 20q13 in breast cancer: Defining the critical region and exclusion of candidate genes. Cancer Res. 54: 4257-4260.

Thompson, C.T. and J.W. Gray. 1993. Cytogenetic profiling using fluorescence in situ hybridization (FISH) and comparative genomic hybridization (CGH). J. Cell Biochem. (Suppl.) 17G: 139-143.

Tsujimoto, Y., J. Cossman, E. Jaffe, and C.M. Croce. 1985. Involvement of the blc- 2 gene in human follicular lymphomal. Science 228: 1440-1443.

Xiao, Z., J.T. McGrew, A.J. Schroeder, and M. FitzGerald-Hayes. 1993. CSE1 and CSE2, two new genes required for accurate mitotic chromosome segregation in Saccharomyces cerevisiae. Mol. Cell. Biol. 13: 4691-4702.

Received November 2, 1995; accepted in revised form February 8, 1996. 


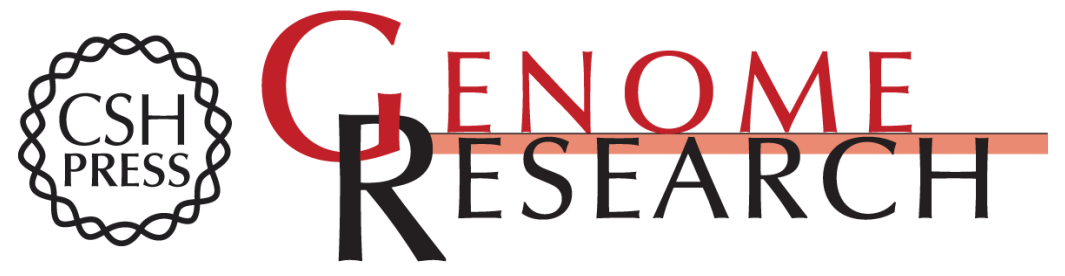

\section{The human CAS (cellular apoptosis susceptibility) gene mapping on chromosome $20 \mathrm{q} 13$ is amplified in BT474 breast cancer cells and part of aberrant chromosomes in breast and colon cancer cell lines.}

U Brinkmann, M Gallo, M H Polymeropoulos, et al.

Genome Res. 1996 6: 187-194

Access the most recent version at doi:10.1101/gr.6.3.187

References This article cites 15 articles, 7 of which can be accessed free at:

http://genome.cshlp.org/content/6/3/187.full.html\#ref-list-1

\section{License}

Email Alerting Receive free email alerts when new articles cite this article - sign up in the box at the Service top right corner of the article or click here.

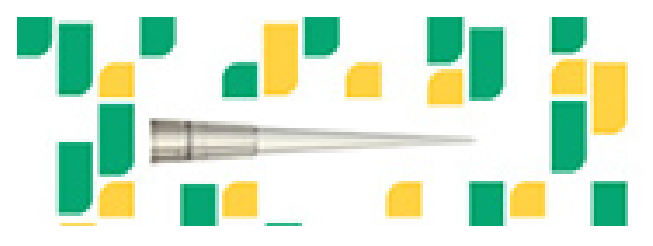

Focused on your science.

To subscribe to Genome Research go to:

https://genome.cshlp.org/subscriptions 